\title{
The digital citizenship of children and adolescents: Challenges for social work education
}

La ciudadanía digital de las infancias y adolescencias. Desafíos para la formación en Trabajo Social

La ciutadania digital de les infàncies i adolescències. Desafiaments per a la formació en Treball Social

Antonia Picornell-Lucas ${ }^{1, *(\mathbb{D})}$, Antonio López-Peláez ${ }^{2}$

1 | Universidad de Salamanca, Salamanca, España

2 | UNED, Madrid, España

*Corresponding author: toi@usal.es (Antonia Picornell-Lucas)

ABSTRACT: The digital and superdiverse societies of which we now form part require a redefinition of social work and social services to address the digital citizenship of children and adolescents. This article analyzes the main challenges in this area, which can be addressed through digital social work.

KEYWORD: digital citizenship; childrenhood; adolescents; digital social work

RESUMEN: Las sociedades digitales y superdiversas en las que nos encontramos inmersos demandan una redefinición del trabajo social y de los servicios sociales para abordar la ciudadanía digital de los niños, niñas y adolescentes. En este artículo analizamos los principales retos que afrontamos en este ámbito, y que pueden ser abordados desde el trabajo social digital.

PALABRAS CLAVE: ciudadanía digital; infancias; adolescencias; trabajo social digital

Citation: Picornell-Lucas, A \& López-Peláez, A. (2022). The digital citizenship of children and adolescents: Challenges for social work education. Research in Education and Learning Innovation Archives,

28,32-37.

$10.7203 / 28.23001$

Copyright: The Authors. Open Access: This article is distributed under the terms of the Creative Commons Attribution-NoDerivatives 4.0 International licence (CC BY-ND 4.0)

Funding: None informed
RESUM: Les societats digitals i superdiverses en les que ens trobem immersos demanden una redefinició del treball social i dels serveis socials per a abordar la ciutadania digital dels xiquets i adolescents. En aquest article analitzem els principals reptes que afrontem en aquest àmbit, i que poden ser abordats des del treball social digital.

PARAULES CLAU: ciutadania digital; infàncies; adolescències

\section{INTRODUCCIÓN}

The comprehensive protection of children and adolescents is among the most important features of contemporary democracies and has become a priority of welfare systems. Over the years, the definition of comprehensive child protection has evolved to encompass an integrated approach to children's development where the best interests of the child are the primary consideration, as set out in the Convention on the Rights of the Child (UN, 1989). This approach has given rise to new social work practices (Liebel, 
2021) and placed the focus on the participation of children and adolescents from diverse regions and sociopolitical contexts.

There is a long tradition of empirical work and longitudinal studies on theories of childhood (James, Jenks, \& Prout, 1998), children's right to citizenship (Gaitán, 2018; Villagrasa \& Lepin, 2021), and public redistributive and pre-distributive capacity and child policies (Ayala, Cantó, Martínez, Navarro, \& Romaguera, 2020; González-Bueno, 2020). Comparative research has also been conducted on children's subjective wellbeing (Casas et al., 2014) and migrant children (Skivenes, Barn, Kriz, \& Pösö, 2015). Additionally, given the focus on child protection within welfare systems, austerity policies and their impact on service delivery has been the subject of comparative analyses López-Peláez and Gómez-Ciriano (2019), while the debate surrounding the conflicting ethical and legal principles that guide the decisions of child welfare professionals has also been examined (Berrick, 2018).

Digital transformation, and its effect on processes of social exclusion and inclusion, has been a topic of growing concern among professionals, citizens, and legislators and led to the enactment of citizens' digital rights. In 2018, prior to the COVID-19 pandemic, the Spanish Data Protection Act (Ley Orgánica 3/2018, de 5 de diciembre, de Protección de Datos Personales y garantía de los derechos digitales [LOPDGDD]) was passed unanimously. Title $\mathrm{X}$ of the Act includes provisions on the digital rights of all individuals. The Act also specifically establishes the obligation to protect the fundamental rights of children (Art. 76) and ensure the responsible and balanced use of digital devices and social networks (Art. 84) and the processing of personal data (Art. 7).

The pandemic has hastened the pace of the digitalization processes in which we have been immersed for decades. As a result, professional practices have changed, new needs and demands have emerged, and training in digital skills has become essential for both users and social work practitioners. From a legislative standpoint, on 14 July 2021 the Spanish Government presented the Charter of Digital Rights (Carta de Derechos Digitales, CDD) to protect the digital rights of all citizens. ${ }^{1}$ Likewise, the UNESCO member states adopted the first global agreement on the ethics of artificial intelligence (EIA) on 22 November $2021 .^{2}$ Both documents underline the importance of monitoring potential risks and practices in the digital environment that may infringe on the freedom and development of children and young people.

\section{DIGITAL CITIZENSHIP OF CHILDREN AND ADOLESCENTS: A PRIORITY IN 21ST-CENTURY DIGITAL SOCIETIES}

In discussions on the protection of children and adolescents, it is necessary to remember that human beings are first and foremost makers of technology; we are builders of machines, and that not only physical, but also social relations and strategies are technologies. In this regard, in a digital society there is no social inclusion without digital inclusion. Therefore, we need to design social policies that will ensure the digital well-being of children and adolescents. Without digitalization there is no inclusion, and the digitalization model we are implementing in social services will have lasting consequences. As the digitalization model is not neutral, it is important to introduce some key points in the debate.

Firstly, the rights of children and adolescents must be protected; rights that are increasingly being decided upon in the digital sphere, as occurs with the rest of the citizenry. Because our institutions are being digitalized and an increasing number

\footnotetext{
${ }^{1}$ https://www.lamoncloa.gob.es/presidente/actividades/Documents/2021/140721-Carta_Derechos_Digita les_RedEs.pdf

${ }^{2}$ https://es.unesco.org/artificial-intelligence/ethics
} 
of services and benefits are now delivered through a digital gateway, it is essential that both social workers and children acquire the necessary digital skills to navigate these systems. The digital divide is not only a question of accessibility, but also one of usage, skills, and trajectories. Children and young people are learning to communicate in a multimodal manner (one that is often incomprehensible to adults), create content, and define their emotional well-being through digital platforms (i.e., via likes on their social network profiles, professional gamers, YouTubers, etc.). In short, they are constructing a generational identity in virtual social spaces where they can express their opinions freely. At the same time, however, they demand safe and trustworthy digital infrastructures, according to a study by Safer Internet Centre Spain with Generation Alpha children conducted in the framework of a European project (Rangel, Monguí, Larrañaga, \& Díez, 2021).

A second issue is how to deliver the services we provide. Because many of our users are confined due to the pandemic, it is important that we devise ways to conduct Internet- and technology-based interviews, home visits, and diagnoses and interventions, particularly for children in situations of vulnerability. We must also inquire into how we can turn digitalization into an opportunity to improve social services and provide better care to children and adolescents. Other issues concern how to co-design the incorporation of digitalization and the new hybrid model of digital and face-to-face care jointly with users and professionals (López-Peláez, Aguilar-Tablada, Erro-Garcés, \& Pérez-García, 2021) or how to prevent children's development, social relationships, and personal safety from being affected by the intensive and non-responsible use of digital technologies.

Thirdly, children's digital rights, as well as digital interventions and digital competence, must be integrated in higher education curricula. Indeed, it is essential that social workers be trained to intervene in very specific environments, including digital ones. To this end, technological knowledge and skills must be given priority in higher education training and research, while the teaching-learning environment should engage students in the elaboration and construction of their own knowledge grounded in critical and ethical thinking. Although we cannot eschew face-to-face interventions, the growing digital environment requires specific training in digital skills (LópezPeláez, Erro-Garcés, \& Gómez-Ciriano, 2020).

The fourth question concerns the due recognition of scientific knowledge, that is, the expert knowledge of scientists, including that of social scientists and, of course, of social work practitioners. In a context of populism, radicalization, and fake news, where scientists and experts are being questioned, it is necessary to underline the importance of the right to rigorous information and to a professional evaluation based on expert knowledge and science, including the social sciences (López-Peláez, MarcuelloServós, De-Mesa, \& Almaguer-Calixto, 2020). In this line, the UN Committee on the Rights of the Child highlighted the crucial role of research to better understand the effects of digital technology on children's development in its General Comment No. 25 (2021) on children's rights in relation to the digital environment.

Against this backdrop, our special issue examines a key issue that builds on studies carried out to date: the digital citizenship of children and adolescents and the challenges it involves regarding social work training. The articles selected for this special issue explore the link between technological-digital culture and the development of children's citizenship, and the impact of this changing scenario on training in the competencies, skills and knowledge of social work students. The issue includes contributions by Ibero-American authors from Brazil, Portugal, and Spain that address the digital reality of children and adolescents and assess methodological challenges regarding the construction of knowledge in digital social work.

The first contribution examines a good practice in digital participatory action research carried out in Portugal during the health emergency. Patricia Vegard, Helena 
Belchior-Rocha, and Inês Casquilho-Martins (Vegard, Belchior-Rocha, \& CasquilhoMartins, 2022) analyze this experience, in which technical teams that provide training in family assistance and undergraduate social work students participated. The aim was to promote positive interactions and empower certain families from a children's rights approach. The authors highlight the families' receptiveness to digital technology platforms and their digital competencies. The authors also emphasize the capabilities (flexibility and critical analysis) of both the technical intervention teams and the students to adapt face-to-face interventions in homes to virtual environments and demonstrate that digital technology can complement both social work training and professional practice.

The e-society has emerged due to the transformation of interpersonal relationships, education, work, leisure, and personal well-being. These new forms of socialization, which have arisen due to processes of computerization and digitalization, have brought new opportunities for democratic engagement, but can also widen the inequality gap in rights. As Ilana Lemos de Paiva and Gabriel Miranda's reflections on the Brazilian reality (Lemos de Paiva \& Miranda, 2022) indicate, digitalization may become a form of social domination; an instrument of social and labor inequality that may compromise our collective welfare. Through a well-documented study on the writings of Karl Marx, for whom work enables human beings to advance towards their realization as social beings, they bring to light the impact of digital capitalism on the lives of working people: the loss of value of working time, the assumption of costs derived from labor activities, labor deregulation, and unequal access to technology; in short, labor exploitation on digital platforms. For all these reasons, the authors highlight the key role higher education institutions have in preparing students for professional practice with a social interest. They stress the importance of university students acquiring the ability to position themselves critically in the work environment to prevent the suppression of labor rights and the consequent "uberization of work."

Rafael Nicolau Carvalho, Carlos Eduardo Ferreira Monteiro, and Maria Niedja Pereira Martins (Carvalho, Monteiro, \& Martins, 2022) bring us closer in contact with the Generation Alpha. The term, which was coined by Mccrindle (2009), refers to the current generation of young people born after 2010, the children of the Millennials. This generation is characterized by its permanent connection with social networks and electronic devices. In reference to the Brazilian population as an example of cultural and socioeconomic diversity, the authors question the technological specificity of the Generation Alpha and argue that the identifying characteristics of these children cannot be considered static, since they are produced in a variety of social contexts. Despite this premise, they focus their attention on the training of future professionals. Specifically, they seek to better understand the impressions and digital capabilities of students at the Universidade Federal da Paraíba, Brazil, which although basic, are essential skills for future professional practice with the new social generations. As the results of this qualitative research indicate, students demand alternative teaching-learning models based on participatory and democratic methodologies that integrate digital technologies and promote digital inclusion. Moreover, to contribute to the teaching-learning process and ensure effective professional interventions aligned with the heterogeneous realities of children, it is necessary that teachers critically assess their own technological training.

The capacity for critical thinking and empowerment, which weaves through the previous texts, is also addressed in the contribution that concludes this special issue. José Luis Fernández-Pacheco Sáez, Irina Rasskin Gutman, and Eduardo Marques (Fernández-Pacheco Sáez, Rasskin-Gutman, Marques, \& Yoshihama, 2022) -all of whom are specialists in participatory action research-examine the potential of digital PhotoVoice methodology in several experiences carried out in Portugal and Spain. 
From a broad theoretical proposal, they describe the application of this methodology in different projects, all of which aim to improve emotional and social skills. The authors present diverse cases in the framework of the Erasmus+ ESCUTA project (2020-2023): from homeless people in the Azores Islands to teenagers from an school in Cáceres, Spain, and university students from both countries. They highlight the enormous potential of (Digital) PhotoVoice in community social interventions and social research to build collective identities and contribute to a social transformation that prioritizes equal opportunities.

\section{CONCLUSIONS}

In digital societies, democracy can only be viable if it is based on inclusive digitalization. The rights of children and young people must be extended to the digital environment because their citizenship is conditioned precisely by this virtual world. Many of their problems and opportunities, their forms of communication and relationships, their way of understanding the world, will be intrinsically linked to the digitalization model in which we are immersed.

To ensure that children and adolescents are properly cared for, supported, and protected in the digital environment, and to respond to the challenges we have previously analyzed, it is essential to develop a professional intervention model based on a threefold strategy:

- Democratically colonize virtual platforms, including metaverse, and provide spaces for active engagement.

- Ensure the presence of professionals dedicated to the defense of human rights and equal opportunities, as well as professionals who can implement innovative strategies and methodologies and understand and transform the risks inherent to the digital reality.

- Training in digital skills is already a priority in professional practice but must also play a relevant role in the training of future social workers and social welfare professionals. Training must focus on versatile professional practices and research. Training from the approach of children's digital citizenship will ensure a safe and free digital environment for all children and adolescents in their new vital and virtual realities.

This is a decisive challenge in the training of future social workers. In this sense, digital social work has become a specialization in recent years and is increasingly integrated in social work training programs with a basic objective: the design of better professional interventions in the digital environment (González, Astray, \& Puelles, 2021).

\section{REFERENCES}

Ayala, L., Cantó, O., Martínez, R., Navarro, C., \& Romaguera, M. (2020). Análisis de las necesidades sociales de la infancia. Informe Observatorio Social. Barcelona: La Caixa.

Berrick, J. D. (2018). The impossible imperative: Navigating the competing principles of child protection. New York: Oxford University Press.

Carvalho, R. N., Monteiro, C. E. F., \& Martins, M. N. P. (2022). Challenges for university teacher education in Brazil posed by the Alpha Generation. Research in Education and Learning Innovation Archives(28), 61-76. Retrieved from https://doi.org/10.7203/ 28.21408 https://doi.org/10.7203/28.21408 
Casas, F., Castellá, J., Alfaro, J., González, M., Figuer, C., Abs, D., ... Oyarzún, B. (2014). Satisfacción escolar y bienestar subjetivo en la adolescencia: poniendo a prueba indicadores para su medición comparativa en Brasil, Chile y España [School satisfaction and subjective well-being in adolescence: testing indicators for comparative measurement in Brazil. Suma Psicológica, 21(2), 70-80. https://dx.doi.org/ 10.1016/S0121-4381(14)70009-8

Fernández-Pacheco Sáez, J.-L., Rasskin-Gutman, I., Marques, E., \& Yoshihama, M. (2022). (Digital) PhotoVoice y su papel en el Desarrollo Comunitario y la construcción de la identidad colectiva: hacia una ciudadanía crítica y participativa a través de la educación. Research in Education and Learning Innovation Archives(28), 77-92. https://doi.org/10.7203/28.21795

Gaitán, L. (2018). Los derechos humanos de los niños: ciudadanía más allá de las "3Ps". Sociedad e Infancias, 2, 17-37. https://doi.org/10.5209/SOCI.59491

González, D. A., Astray, A. A., \& Puelles, A. A. (2021). Social work in digital societies. Madrid: McGraw Hill.

González-Bueno, G. (2020). La medición de la inversión pública en la infancia: justificación y propuesta metodológica [Measuring public investment in children: justification and methodological proposal. Presupuesto y gasto público, 98, 79-94.

James, A., Jenks, C., \& Prout, A. (1998). Theorizing childhood. Cambridge, UK: Polity Press.

Lemos de Paiva, I., \& Miranda, G. (2022). Contribuciones para una mirada marxista acerca de los usos de la tecnología bajo el capitalismo. Research in Education and Learning Innovation Archives(28), 50-60. https://doi.org/10.7203/realia.28.21421

Liebel, M. (2021). La niñez popular. Intereses, derechos y protagonismos de los niños y niñas. Madrid: Catarata.

López-Peláez, A., Aguilar-Tablada, M. V., Erro-Garcés, A., \& Pérez-García, R. M. (2021). Superdiversity and social policies in a complex society: Social challenges in the 21st century. Current Sociology. https://doi.org/10.1177/0011392120983344

López-Peláez, A., Erro-Garcés, A., \& Gómez-Ciriano, E. J. (2020). Young people, social workers and social work education: The role of digital skills. Social Work Education. The International fournal, 39(6), 825-843. https://doi.org/10.1080/02615479.2020 1795110

López-Peláez, A., \& Gómez-Ciriano, E. J. (Eds.). (2019). Austerity, social work and welfare policies: A global perspective. Pamplona: Thomson Reuters Aranzadi.

López-Peláez, A., Marcuello-Servós, C., De-Mesa, J. C., \& Almaguer-Calixto, P. (2020). The more you know, the less you fear. Reflexive social work practices in times of COVID19. International Social Work, 63(6), 746-752. https://doi.org/10.1177/0020872820959365

Mccrindle, M. (2009). The A B C of X Y Z: Understanding the global generations. Australia: McCrindle Research Pty Ltd.

Rangel, C., Monguí, M., Larrañaga, K. P., \& Díez, O. (2021). Las marcas como eje de socialización de la Generación Alpha [Brands as the axis of socialization of Alpha Generation]. Prisma Social, 34, 124-145. Retrieved from https://revistaprismasocial.es/ article/download/4361/5012/20332

Skivenes, M., Barn, R., Kriz, K., \& Pösö, T. (2015). Child welfare systems and migrant children: A cross country study of policies and practice. New York: Oxford University Press.

Vegard, P., Belchior-Rocha, H., \& Casquilho-Martins, I. (2022). Digital interventions with families - a case study. Research in Education and Learning Innovation Archives(28), 37-49. https://doi.org/10.7203/realia.28.21413

Villagrasa, C., \& Lepin, C. (2021). Los derechos de la niñez a través del cine. Barcelona: Huygens. 